\title{
Dressing the law
}

\author{
Aoife Monks* \\ School of English and Drama, Queen Mary, University of London \\ *Corresponding author. E-mail: a.monks@qmul.ac.uk
}

\begin{abstract}
The theatre shares many features with the law. One key commonality is the presence of dressers in both professions. In the law and the theatre, the dresser is a key intermediary in the transformation of bodies and the transmission of professional culture, while being relatively under-recognised in criticism and scholarship. The point of departure for this paper is that the dresser is a figure worthy of further scrutiny. As the Court and Ceremonial Manager at Ede and Ravenscroft, Christopher Allen is perhaps one of the common law's most important dressers. Allan is instrumental to the entry of the judiciary into their new roles by dressing them for the very first time in advance of their swearing-in ceremony. Established as a wig-making business in 1726 (later selling robes from 1871), Ede and Ravenscroft are the tailors and robe-makers of choice for the judiciary, not only in England and Wales, but in many common-law jurisdictions. This paper draws upon an interview with Allen about his work as the dresser of the judicial establishment of England and Wales in order to explore the role of dressing up in the production of images of the judiciary. Thinking about the role of the dresser in the production of the judicial image draws attention not simply to the function that dress plays in the law, but foregrounds the process of dressing up as a key aspect of the law's performance.
\end{abstract}

Keywords: dresser; dressing up; costume; judicial dress; Ede and Ravenscroft; theatricality

\section{Dressing the law}

In Ronald Harwood's 1980 play, The Dresser, the often overlooked figure of the backstage assistant comes to light. The Dresser concerns the work of Norman, the long-time dresser of 'Sir', the mentally unstable star actor of an English repertory theatre company during World War II. The play exposes the theatrical half-light that the figure of the dresser occupies. In one of the closing scenes of the play, Norman stands in the shadows during the curtain call for an ill-begotten production of King Lear, prompting Sir from the darkness: 'Sir steps into the light and Norman stands just behind him in shadow. Applause and cheers' (Harwood, 1980, p. 84).

The figure of the dresser emerges in the play as central to the work of the theatre while being overshadowed by its professional hierarchies. Norman's work exposes how the apparently readymade appearance of the virtuosic star onstage is in fact a collaborative effort between actor, dresser, costume-designer and maker. Norman shapes the contours of the actor's body in its presentation to an audience, and he contributes to the regulation of the actor's psychic and emotional borders too. Despite the central role that Norman plays in the production of the actor's presence onstage, his marginalisation within the theatre's hierarchies becomes evident when he discovers at the end of the play that Sir has failed to acknowledge his sixteen years of service in his memoirs. The play underlines what Alice Rayner describes as the 'asymmetry of the relationship between the conceptual and the material practices' of the theatre (Rayner, 2002, p. 545), demonstrating the mismatch between the audience's experience of the illusion onstage and the labour required to create that illusion backstage. 
The theatre shares many features with the law, as has been argued by Julie Stone Peters among others. ${ }^{1}$ One key commonality is the presence of dressers in both professions. In the law and the theatre, the dresser is a key intermediary in the transformation of bodies and the transmission of professional culture, while being relatively under-recognised in criticism and scholarship. ${ }^{2}$ However, this short essay and interview suggests that the dresser is a figure worthy of further scrutiny. Thinking about the role of the dresser in the production of the judicial image not only draws attention to the function that dress plays in the law, but also foregrounds the process of dressing up as a key aspect of the law's performance.

As the Court and Ceremonial Manager at Ede and Ravenscroft, Christopher Allan is perhaps one of the common law's most important dressers. Allan is instrumental to the entry of the judiciary of England and Wales ${ }^{3}$ into their new roles by dressing them for the very first time in advance of their swearing-in ceremony. ${ }^{4}$ Established as a wig-making business in 1726 (later selling robes from 1871), Ede and Ravenscroft are the possessors of three royal warrants as robe-makers to the Queen, the Duke of Edinburgh and the Prince of Wales, and they are, as their website outlines, 'the tailors and robe-makers of choice for twelve coronations. Today the firm continues to service royalty, the judiciary, civic authorities, academia and business' (Ede and Ravenscroft, 2017). In effect, not only do Ede and Ravenscroft - and thus Christopher Allan - dress the judiciary of England and Wales, but they play a central role in dressing the British Establishment.

Allan's work offers a valuable reminder of the role of dressing up in the production of images of the judiciary. In April 2016, I interviewed Christopher Allan about his work dressing judges, fuelled by my scholarly interest in theatre costume and the performance of the law onstage. In this interview, Allan offers his sense of what the role of the legal dresser entails. Just like Norman in Harwood's play, he emerges from this discussion as the custodian and transmitter of tradition and professional values, and as an intermediary figure situated between the craft-based tacit knowledge of the wig and robemakers and the forms of authority produced and consolidated by costume for the judge. Allan's role requires an acute understanding of the historical ancestry and traditions of judicial dress ('why' it is how it is), the craft traditions and practices of producing the robes and wigs, the ritual traditions surrounding the uses of the dress in legal ceremony and practice, and the very practical challenges encountered by the judiciary while working in, and wearing, the clothes.

My interview with Christopher Allan took place at the Bar Room at Ede and Ravenscroft's Chancery Lane shop in April 2016. Allan then took me on a tour of the wig and robe-making rooms in the basement beneath the shop, where the extraordinary skills of the makers were on display. An edited version of this interview appears here, accompanied by a short essay that considers the implications of the figure of the dresser for an understanding of the fragile theatrical equilibrium that underpins the performance of the law. I consider why it might be that legal dressers, as with Norman in the shadows, have been marginalised in official accounts of legal dress, even as they exert remarkable influence over the production of judicial images.

\section{An interview with Christopher Allan}

Aoife Monks [AM]: Can you talk me through the process of fitting a new judge from the beginning to the end? When somebody makes the transition into becoming a judge, what happens when they come to you?

\footnotetext{
${ }^{1}$ See Stone Peters (2008); Read (2016); Nield and Leiboff (2010); Yablon (1995).

${ }^{2}$ I could find no account of the role of the dresser in the law in scholarly discussions of legal dress. The figure of the dresser has rarely been considered by theatre scholars either - Barbara Hodgdon is a notable exception; see Hodgdon (2012).

${ }^{3}$ Ede and Ravenscroft and Allen are also involved in the provision of judicial robes for the UK Supreme Court and a for the judiciary in number of other jurisdictions including Australia, Hong Kong, Nigeria, Scotland and the US.

${ }^{4}$ For work on judicial swearing-in ceremonies, see Moran (2018) and Roberts (2012; 2014).
} 
Christopher Allan [CA]: The process starts once they have been appointed. They are told by the Court Service to contact one of the registered suppliers, which usually means they come to me. I need to see them in the first instance for half an hour. In that half hour we see them in the Bar Room, which has been a principle fitting room at Ede and Ravenscroft since we've been on this site since 1865 . It hasn't always been in this present location but when it's been moved in the building it's been moved to exactly the same proportions every single time. The appointment with a High Court judge or a Circuit is considerably longer than the one for a District Judge, because the District Judges wear the new civil robe, which was designed by Betty Jackson, and is the only judicial robe that we sell off the peg. It's made in five separate off-the-peg sizes. For the other judges, I take them through the items they are going to need and then I'll call up a wig-maker to measure for a new wig, a tailor to measure for breeches or a skirt, and I then take my own set of measurements for the robes themselves.

Men have to be measured for a pair of breeches for under their robes on ceremonial occasions, whereas ladies have the option of breeches or a skirt and that tends to fall about fifty-fifty. Some ladies quite like the idea of dressing up and decide they'd like to try a pair of breeches on just to see what they look like. You tend to find that the women who go for breeches are those who overall like dressing up. You can usually tell them by how they dress when they come in in their civilian clothing. The fact of the matter is that you can't actually see the breeches or skirt underneath the robe, so only they know what they are wearing underneath. The men will try on some buckled court shoes, and with ladies we ask them to supply a pair of black patent shoes and we will put buckles onto them.

We then establish what they want on their wig tin, which is the box their wigs are kept in, with their name inscribed in gold lettering on the outside. It keeps the wig in good condition. Since the robes are bought on a requisition basis, the items are ultimately paid for by the tax-payer and therefore on the retirement of judges that were appointed from 2008 all the clothes will go back to HMCTS (Her Majesty's Courts and Tribunal Service).

On the day of the swearing-in, we used to dress the new judges in the Bar Room, but it has to be done at the Royal Courts of Justice (RCJ) now, after the Charlie Hebdo attacks in Paris. ${ }^{5}$ When we did it at the Bar Room, once the new judge was fully dressed, their party of guests came to the shop. Then there was the reveal moment: they came in here as a man or a woman in a suit and then they emerged fully dressed as a Circuit Judge, full wig and everything. What's always amusing is, as you open the door, the family are outside and they are all in their best clothing and finery because it's a big day in someone's career and life, a defining moment. And far from the family being in awe of the majesty of the law that is before them, their first response is mirthless laughter, just absolute laughter. This is especially true amongst small children who find it abso-

\footnotetext{
${ }^{5}$ On 7 January 2015, the Paris office of a satirical magazine Charlie Hebdo was attacked by two people who identified themselves as belonging to the Islamic terrorist organisation al-Qa'ida. Twelve people died and eleven were injured. Several related attacks followed in the region around Paris. In the wake of these incidents, security in the UK in general and London in particular was increased. The Bar Room of Ede Ravenscroft is on Chancery Lane about 300 meters from the RCJ.
} 
lutely astonishing to see Mummy or Daddy dressed up like that. They seem totally alien: it's just very peculiar to see someone you've known at home in their slippers or ripped jeans to now view them in such an alien costume. Most guests haven't seen full ceremonial dress before; it's the first time they've been exposed to it. I say to all new judges, this is what will happen on the day: 'You will get dressed here, we will open the door and your family will fall to pieces.' It's the same response every single time: laughter.

AM: Do you have a ritual that you follow when you dress somebody?

$C A$ : Having done this for twenty-five years now, I've sort of developed my own way of doing it: I have my routine. I've got my usual jokes, which become punctuation points for me in the process, so that I don't forget something. For example, when I'm dressing a Circuit Judge, once I've got most of the clothing on I say: 'Right, I don't think you're anything near warm enough today, I think you need another layer of clothing - I think we're going to put a hood on you.' And then I show them the hood and say: 'Right, how do you think you're going to put that on then?' And they look at it vaguely aghast. The only time they've ever encountered one is in an academic ceremony. You show them how to tie it on and then you say: 'You can't actually tie it yourself. But if you can do it yourself, you will be immediately promoted to the High Court Bench, because one very little known fact is that all High Court judges are double-jointed.' And that puts them at their ease, because of the silliness of the situation. They realise that they can't actually put the hood on themselves and wonder what will happen next time. I reassure them that the next time that they wear the robes will be at a church service to mark the start of the legal year, or at a ceremony to welcome a new presiding judge on the circuit. They won't be the only judge there and they will all help each other with their hoods when getting dressed.

The ceremony is very short indeed, they just declare an oath in front of the Lord Chief Justice, and then he will go around and chat to everyone in their party and then he will withdraw after about half an hour. The new judge comes back to me and I disrobe him or her. My opening gambit is usually: 'Right well, you're a judge now, no backing down. Signed, sealed, and delivered.' This is because they come in carrying the red wallet that has the warrant in it, so there's no backing out once the ceremony is completed.

$A M$ : What's their emotional state at that point and throughout that process?

$C A$ : When they come in for that first appointment they are trepidacious to say the least. So when they come in first I say: 'Congratulations.' They tend to be in quite a happy mood but also trepidacious because they are so unsure about what the process actually is, mainly because HMCTS are like any major civil service organisation staffed by people who don't quite understand what the process is themselves, and are often relying on tenth-hand notes for what goes on. So I find that after I first meet with them, they say: 'Well I'm very pleased with this half hour because I know now more about this process than anyone has been able to tell me up until this point.'

$A M$ : So you're not only fitting them for robes, you are also enabling them to make their transition into the judiciary?

CA: Absolutely. On the day of the ceremony, they are clearly going to be nervous because they are going to be meeting the Lord Chief Justice. There's a degree of trepidation because you've been appearing in front of these people as a lawyer, and now you are becoming one of these people. It's the gamekeeper/poacher type thing: you are crossing a line. It's a case of calming them down that day. Even though I'm teaching them how to dress they're not going to be taking it all in, because they are actually quite petrified about whether they will get through the oath without messing it up. Bearing in mind that words are their currency, it's quite surprising how nervous they get about it. 
It's a case of trying to keep them calm and then when they come back after the ceremony they are intensely relieved. I always tell them to choose a morning swearing-in if they can. If you get sworn in in the afternoon then you'll have to have a lunch - you're not going to enjoy it or notice what the food is. If you want to enjoy the day, choose the morning swearing-in ideally at 11 a.m. - and then you can go onto a restaurant and enjoy your meal. It's one of the things that they don't think about, but over twenty-five years I've observed that of the ceremonies, and I now incorporate it into my spiel.

AM: When you dress the new judges do you see them change? Do they begin to move differently or stand differently? Do they have a different emotional conduct because of the dress?

CA: Yes. They don't slouch any longer. They stand to attention. You could say that judicial processions move at a dignified rate. I put that down to the shoes. The shoes are quite slippery - they are effectively slippers. If you took the buckles off, they would be a pair of house slippers, and walking outside wearing house slippers is precarious. So the reason why they walk slowly is that they can't keep their shoes on. With High Court judges it's also because the outfit is so heavy. You wouldn't want to be moving at any great rate in those robes.

$A M$ : Does the class background of lawyers determine how they relate to you and the process of robbing?

CA: There are those that are delighted, and those that see it as par for the course, and that will make a difference to how you tackle the hour with them. Criminal practitioners are utterly different to commercial lawyers. And then you get the lawyers who have utter disdain for tradition and regard the entire thing as pompous. I sometimes go to the silk ceremony at Westminster Hall to see the end result of having worked for six weeks solidly, doing seven days a week. It's always interesting seeing the silks ${ }^{6}$ who were objecting to getting dressed up having photo after photo taken. It's interesting to see how people's views change. I think the purpose of the clothes suddenly becomes real to them on the day of the swearing-in. You're at Westminster Hall, it's all very grand and it's the number of people dressed in the same way that you are. That's how they relax into it: it's safety in numbers.

Then of course when they start making court appearances, they no longer dress in junior dress, they now sit at the front of the court in their Q.C. sleeved-waistcoat, their bum-freezer jacket and the Q.C.'s gown. And it's interesting to see the change there in people, suddenly they start taking this idea of dressing up much more seriously, because it is a rank and a badge of honour and it distinguishes them from the rest, and even the most ardent of objectors have a tendency to settle into their clothes.

AM: What does your job actually comprise? What do you have to be good at?

CA: The most important thing for me to have is confidence - to not be intimidated by the people that you meet because some of them are naturally intimidating. You've got to have a degree of confidence in yourself otherwise you'll crumble. While judges are very important people, the only way you are going to get to the end result is if you take the lead - they've got to have confidence in me.

I treat them as equals, I think: 'I'm the expert here and you aren't. If I came to you for legal advice I wouldn't question what you were telling me, so I would expect the same thing from you'. And by and large they will acknowledge the fact that I'm the expert and they are in my hands, and I will lead them through this process. I will research the type of practice they are in and will therefore adjust my sales pitch. The usual thing is that I greet them at the front door, and I call them by name and introduce myself and try to put them at ease. They come into this place with the chandeliers and it can be intimidating,

\footnotetext{
${ }^{6}$ 'Silks' is a colloquial term used for members of the legal profession who have been awarded the title Queen's Counsel (also known as Q.C.). Appointees wear silk gowns of a particular design. Appointment is known as 'taking silk'. Appointment is based on merit and requires a particular level of expertise and experience in law. It is a status particularly associated with barristers and, in Scotland, advocates.
} 
and we have to break that down straight away. Right from the outset I am stamping my authority on the situation. We are going to do this my way. Not your way. My job is to establish what the clothing order is, to raise orders for the production department, and also progress chasing and project managing. I do eighty to ninety hours a week if I'm doing silk, to the exclusion of anything else.

AM: You obviously serve Ede and Ravenscroft and that is a commercial concern. But it also sounds like you induct judges into their new roles and you know more about how the entire legal system works more than any one of those people do: you are actually playing a really important role for the legal profession as well as Ede and Ravenscroft?

$C A$ : Yes. It comes from the number of years I've been doing this, twenty-five years, which means that lots of people are outstripped by me. I've become a repository for memory for how the system works. In other positions in the Court Service or the Royal Household, or in Parliament, office-holders change all the time. I'm the continuity link - rather than searching through their files, people just ring me.

It's not just a role where you're selling somebody something. You're actually trying to guide them through a process. I realised that new judges were getting absolutely no guidance from anybody else. Increasingly therefore people started relying on me to do that. I enjoy it. I get to meet lots of interesting people and a few rogues as well, a lot of people who are officers and holders of big offices.

The Lord Chancellor for example. You get a new Lord Chancellor coming in, after a cabinet reshuffle. He has to be sworn in by the Lord Chief Justice at the RCJ, and he can't constitutionally carry out his duties until he is sworn in, so they want him to get sworn in as quickly as possible. This means his private office will send him over to me straightaway to get his new clothing. The private office has just put him into a car and frankly he's only been appointed to the position for six hours, and he has no idea why he's here. And again, you tell them what he is going to get, you show him photographs of what he is going to be wearing, because it is quite daunting. You speak about some of his predecessors, usually during the measuring when the tape measure is going around his waist and he's going 'Oh dear' and you say: 'Don't hold it in.' I tell him; 'You should stand as if you're in a pub. Because that's how you stand relaxed: belly hanging out. People do not stand to attention. If you stand like that it means we're going to make something that means you have to stand like that forever. There's always someone you can reassure them with. It's a case of trying to make them relaxed - if they're relaxed and confident in you they effectively won't interfere and you can get on with doing the job you need to do for them.

$A M$ : So you are the person who holds the memory of how these roles and customs work - you link up the different rituals of the establishment?

CA: $\quad$ Yes, I suppose so.

$A M$ : How did you end up getting into this job? Is your family background in tailoring?

$C A$ : By mistake is how I ended up here - it was supposed to be a year. I did a degree in law because I was stupendously badly advised in school. I wanted to do history for my A-levels and the career advice was to do law. I was told not to do a history degree - I have a massive regret about that - I'd have loved to have done history. Three years of academic law was quite enough to make me realise that the last thing I wanted to do was become a lawyer. To fund my way through the degree I started working in retail as the Saturday boy and I really enjoyed it. I decided to work in retail for a year after I graduated and then a job came up here. And I'm still here twenty-six years later.

$A M$ : It sounds like you found your way back to historical study since it's so important for your work here.

CA: I loved it from the moment I got here. I remember looking at the job of Court and Ceremonial Manager and thinking that I'd love to do it. And then about four years into my stint here, Bill 
who was doing the job died suddenly, and there had been no proper contingency planning and they thought; 'Who do we send out to the royal household? Who do we send out to the city and livery companies?' In those days I used to really enjoy wearing smart suits and I was confident in myself, and they thought I sounded well-spoken so I got the job on that basis - I looked the part and they thought I'd be ok. But of course if you've got a man who drops dead on the spot, all the knowledge went with him because it hadn't been written down. So a huge amount of knowledge was lost. So I started from scratch - the way we do Q.C.s and judges now is entirely how I thought it should be done by feeling my way through and you finesse the process each year until you just roll it out. Each Q.C. and judge needs the same information and the best way to ensure they're not missing anything is to effectively stick to a script because then you know they've got the information and they were all told it and they've made a reasonable judgment on what they should buy.

$A M$ : What about the makers of the wigs and robes? How are they trained?

CA: There's no formal apprenticeship system. We get lots of people wanting to work for us which I think is an interesting reaction from younger people about the digital age. It's so transient and there's a hunger among youngsters to do something that leaves a mark.

$A M$ : Do the makers ever go to the ceremonies? Do they ever meet the wearers?

CA: I try to make sure they go to the ceremonies. I try where possible to make sure we get a photograph if they're making a robe for a chancellor or a vice-chancellor, and a note from the person wearing it, so that they get to see the finished product actually being worn. That gives them a lot of satisfaction.

AM: In the theatre, critics often talk about costume as if it's only there for the show and the audience. But when I talk to makers of costume, they're not usually that worried about the show, they are more concerned about what other makers will think of them and their work. Sometimes they put huge amounts of labour into something that no one will notice, including the actor. What are the wig- and robe-makers proud of and what are they worried about what's at stake for them?

CA: That's something I was discussing the other day with our head robe-maker when we were discussing a robe ornament she was making. We were discussing how the ornamentation had been sewn on the wrong way round, and we agreed that we couldn't use it. But the point is that the end user would have absolutely no idea that it was the wrong way round: they would never notice a detail like that, which is so small. But we did notice, and our approach here has always been: if we notice, it has to be corrected. The point is not getting away with it because the customer wouldn't notice. The point is pride in what you're doing and the accuracy of what you are doing. Because otherwise you end up with design and ornamentation where you suddenly think: 'Why's that like that?' I've seen it in academic dress and regimental uniforms. I think the reason is that a mistake was made once, and then it was replicated and changed slightly, and then again and again and then you end up with something where you think: 'Why the hell is it like that?' It makes no sense at all. And sometimes the most prosaic answer is that the tailor buggered it up and it's been replicated for years. That is what happens if you start letting standards slip like that.

AM: Presumably this ethic, knowledge and skills emerge through generations of cultural memory: it's all being passed down through generations of makers who are all training each other.

CA: When we have robes in for the Queen that's when it really hits home. When you're doing repair on one of the Queen's robes and it's a robe the makers have seen her wear on television, then that does sort of bring home the traditions that we are working within.

$A M$ : So there's pride in work for its own sake for the makers, quite beyond what it's serving for anybody else? Do you think your pride in work transfers into the authority you show when you work with the judiciary?

CA: The people who work for me are making this stuff to the absolutely highest standards. I don't have any qualms whatsoever justifying that a robe will cost you $£ 22,500$ plus VAT. I can justify 
that entirely because it's worth every single penny, because of the craftsmanship, the work, the gold materials, everything about that is right. The ethic is why you end up with the three royal warrants we've got - because we can be relied upon, because the work will get done properly.

\section{Essay: costuming the law}

Getting the work done properly is an ethos of craftwork and is one of the values that inform the work of the dresser. This interview with Christopher Allan reveals how the dresser navigates between traditions of making and wearing, between the practices of craft and the law, and between the individual body of the judge and the abstracted figure of the law embodied in judicial dress. In this short essay, I suggest that the dresser is crucial to the production of judicial imagery, but is marginalised in official accounts of legal dress. I argue that this marginality may result from the fact that foregrounding the work of the dresser disturbs the careful management of theatricality that underpins legal performance. The figure of the dresser draws attention to the fragile equilibrium of theatrical display and the production of 'truth' that legal dress both enables and threatens. It is worth considering the implications for the law's theatricality when the dresser steps out of the official shadows and comes into view as instrumental to the production of judicial images. Before I consider this question of theatrical equilibrium, however, I will examine the implications of my interview with Allan by considering the various forms of 'backstage' work that informs the act of dressing up for the law.

\section{Backstage dressing}

In her 1976 critique of the spatial and spectacular organisation of the magistrates' court, Pat Carlen argues that the spectacle of the court is a central component of the law's performative power. The court is organised visually in order to authorise the power of legal performance, insisting on an asymmetrical power relation between judge and defendant. As she puts it:

'In contrast to their unceremonious and coercive presentation of defendants, magistrates, policemen, solicitors, and other court personnel all project visual images of themselves and verbally embellished images of each other which are designed to personify the absolute propriety of their situated (judicial) actions.' (Carlen, 1976, p. 53)

Here, Carlen points to the function of the image of the magistrate and the space and architecture of the court as a form of visual rhetoric, situated within a larger visual system of persuasion (or coercion) that includes language, spatial organisation and architecture. This visual rhetoric is also embodied in judicial dress. As Leslie Moran has argued: 'The values and virtues of judicial office, such as judicial independence, obedience to the law and dedication to the promotion and realisation of legal policy are made public in and through visual images of the judge' (Moran, 2016, p. 159). What Carlen and Moran do not mention, however, is that the appearance of the judge is not ready-made. The judiciary must get dressed in advance of their public appearance, and this act of dressing up is artfully concealed in backstage spaces invisible to the public eye. Indeed, maintaining the power of the law may rely to some degree on this act of concealment.

Christopher Allan's interview reveals that the visual codes of the judiciary, presented, as Carlen argues, as the personification of propriety (ibid., p. 53), emerge 'backstage' through the process of dressing up. However, as with the spaces of the law court, the 'backstage' spaces of the law also make assertions of power and hierarchy through architecture, dress, décor and the forms of work that take place there - in fact there are a number of different forms of 'backstage' space involved in legal dressing. Ede and Ravenscroft's Bar Room, for example, in which the new judge is measured for their robes and dressed in them, is a self-consciously ritualised space, imprinted with historical precedent. The walls of this small, square, wood-panelled room are covered with paintings and photographs of past judges, displayed alongside ornate mirrors and heavy mahogany furniture. The room 
insists on the shop's own ancestry, dating back to the eighteenth century. Of course, as Allan pointed out in an aside during our tour of the building, the Bar Room moved to its current location only when the shop was remodelled in the 1980s - constituting a fine example of invented tradition (see Hobsbawm and Ranger, 1983). Indeed, the plush and ornate interiors of the shops are entirely a product of that recent renovation adding far more modern fixtures and fittings replacing those from the earlier part of the twentieth century.

The Bar Room, then, is a room self-consciously designed to insist upon the judge's legal ancestry. The room enables the ritual practice of transformation that takes place through dressing up, through its display of precedence, however imagined or constructed. In fact, Allan reveals that the ritual of robing the new judge for their swearing-in ceremony no longer takes place in the Bar Room, but now happens at the RCJ, due to security concerns. The RCJ then replaces Ede and Ravenscroft as another space of invented tradition, mimicking the architecture of the medieval period while being firmly of the Victorian era, ${ }^{8}$ offering another set of supplementary codes articulating precedence and tradition. The ritualised space of the 'dressing room' mimics and mirrors the ritual space of the law court itself, but with the dresser rather than the judge in charge. The act of dressing up then becomes a transaction of power, in which the dresser organises and controls the body of the judge, so that the dress of the judge can eventually function to organise and control the hierarchies of the courtroom.

It is notable that entry to and exit from these backstage spaces is what bookends the formal ceremony of initiation for the new judge. There is no acknowledgement of Allan's work as dresser within the official swearing-in ceremony and yet his act of dressing and undressing the judge constitutes the borders of that ritual. The judge undergoes an identity transition that requires a period of 'separation' that begins in Christopher Allan's hands in the Bar Room at Ede and Ravenscroft or at the RCJ. This, as Victor Turner explains, is key to the beginnings of any rite of passage or ritual transformation. Separation is 'the phase which clearly demarcates sacred space and time from ... secular space and time. ... which represents the detachment of the ritual subjects ... from their previous social statuses' (Turner, 1974, p. 57). The act of dressing and undressing constitutes a space of separation that forms the borders of the swearing-in ritual but is not officially acknowledged within the ritual itself.

Indeed, as with Harwood's character Norman, Allen himself engages in his own ritualised shadow performance. Allan's description of his process of dressing the judge is centred on his 'patter' - a structured talk, peopled by jokes, which annotates his process of dressing. The concept of patter emerged originally from the religious recitation of prayer, accompanied by structures of bodily movement and gesture. We can see the ritual tendencies of patter reflected in Allan's own structured and rehearsed movement and speech while he dresses the judge. His performance is repeatedly re-enacted for each new judge, marking the beginning and end of the judiciary's own ritual performance. As Barbara Hodgdon describes of the records of theatre dressers backstage: 'the dresser's notes ... reveal a precisely articulated shadow performance, a series of timed actions making up an invisible spectacle' (Hodgdon, 2012, p. 380).

The backstage space emerges in Allan's account as a space of re-enacted performance echoing that of the swearing-in ceremony. Furthermore, Allan's account of the judge's transformation through dressing up suggests that the judges themselves constitute a private audience for their clothes. Allan describes the affective and bodily transformations of judges, who lose habitual slouches, walk slowly to compensate for slippery shoes or become converted to the status of the dress. What emerges from his description is how the production of authority via dress is not a purely decorative or visual process, even if the spectacle of the judge's clothing does the rhetorical work in the courtroom that Carlen describes. Allan's account suggests that judicial dress also enables a form of psychic transformation within the judge through the 'private' experience of wearing it.

\footnotetext{
${ }^{8}$ See Linda Mulcahy (2011) on the architecture and history of the RCJ.
} 
The power exerted by the private experience of dress is a key premise that informed Konstantin Stanislavski's approach to acting at the end of the nineteenth century. ${ }^{9}$ Just as with legal robes, theatre costume was not a purely decorative question for Stanislavski. Rather, it enabled the actor's psychic transformation through the retraining of their emotional reflexes, as he described of the actor's ideal relationship to wearing 'real' dress onstage: 'What is conscious and credible gives birth to truth, and truth evokes belief (Stanislavski, 2008, p. 94). The actor's relationship to costume ideally moves them 'out of the world of objects and into the world of the imagination' (Stanislavski, 2008, p. 69). Costume therefore functions as a vehicle for the emotional transformation of the actor, suggesting the powerful role that dress plays in inducting performers into systems of theatrical belief. It was this Stanislavskian logic that informed Mark Rylance's policy that his actors should wear reproduction Elizabethan underwear at the Globe Theatre (see Silverstone, 2005, p. 36). Here we can see the fantasy that the actors' 'private' experiences of historically accurate costume would infuse their performances with an extra 'truthfulness' that the audience would ideally access indirectly through the authority of their acting, without ever knowing what was taking place 'inside' the underwear.

While this behaviourist logic might not inform how the judiciary self-consciously think of their clothes, it is tempting to wonder whether even the prosaic material impediments of ritual clothing function to cultivate new affective states during the swearing-in ceremony. Allan's interview suggests that judges themselves constitute an audience for the clothing, with the cumbersome robes, slippery shoes, hidden breeches or heavy wigs functioning as a bridge between the ordinary body of the individual and their symbolic abstracted state as 'judge'. Indeed, Gary Watt insists that the struggles of wearing legal dress constitutes an embodied reminder of the responsibilities of the role, with itchy wigs 'reminding the wearer of the constant ethical discomfort that the lawyer should feel in the customary habits of their profession' (Watt, 2013, p. 93). Watt's claim suggests that a continuity exists between the affect induced by the private experience of wearing the clothes and the effects produced by the law. As Alan Read puts it of lawyers' dress: 'They should find the robes of office irritating, ensuring they are alive to the formality and culture of the law as distinct to the nature of the community from which their appellants come' (Read, 2016, p. 19).

Of course, judicial dress has also played an important role in linking judicial bodies to each other, articulating a shared professional identity through the network of clothes. There has been much debate, as Charles Yablon has outlined, around traditions of legal and judicial dress in Britain (see Yablon, 1995). This debate goes to the heart of how the law should 'appear' and the role that dress plays in this appearance. As Penelope Corfield argues in her study of the emergence of the professional classes during the eighteenth century, dress was a key factor in the production of the 'mystery' of professional identity through its claim to expert knowledge. As she puts it: 'Exclusive access to knowledge ... turned the professions into a "mystery" not only in the medieval sense of a cohesive occupational group but also in the alternative sense of sharing a secret, known to the special few' (Corfield, 1995, p. 20). According to Corfield, the emergence and social power of the legal profession relied on the careful guarding of the exclusivity of expertise, managed through specialist training, distinct forms of conduct and, of course, dress, as she puts it: "'mystery" was further sustained by an appropriate demeanour and clothing' (Corfield, 1995, p. 21).

Legal and judicial dress, then, functions to assert a collective professional identity, accompanied by the codes and conduct of a professionalised 'body' in its gestures, bodily control and deportment. This shared set of codes also enables the body of the law to be legible through its adoption of the sober business suit, or the off-the-peg robe, as Alan Read puts it:

\footnotetext{
${ }^{9}$ Stanislavksi was a theatre actor and director who founded the Moscow Art Theatre in 1898 to promote his approach to a Naturalist form of theatre practice. One of the first teachers of a methodical approach to acting training, his influence on acting practice has been widespread (although often misunderstood). For further discussion of the behaviourist logic underpinning his acting theory, see Mitter (1992).
} 
'costuming in law is perhaps the inversion of costuming within the theatre.... in the court room costuming operates to efface the individuality of the legal operators while cumulatively establishing the one thing we must all recognize: the singular face of the law.' (Read, 2016, p. 21)

Indeed, such is the powerfully encoded affect of professional identity, Yablon suggests - half-jokingly that the legal and judicial body is already generic by virtue of its training and interpolation within the values and systems of the law. As he puts it:

'The English have mistakenly confused an effect (court dress) as the cause of lawyerly conformity. The fact is that English lawyers and judges look, sound and act the same way because all lawyers and judges look, sound and act the same way. Anyone who has ever observed an American law school during interview season, with everyone wearing the same blue pinstripe suit, carrying the same resume, and mouthing the same platitudes ... knows that it does not take wigs to remove differences of gender, race and age. All it takes is a first rate legal education.' (Yablon, 1995, pp. 1141-1142)

The law's 'mystery' is maintained through the encoding of bodies as professional through their conduct and dress, rendering them generic whether wearing robes or not. As a dresser, Allan is a key intermediary in this navigation between the everyday bodily experience of individual members of the judiciary and the second 'professional' body that they must adopt as judges. It is notable, then, that Allan is himself conversant with the codes of that world - having taken a law degree - and was chosen for his role because of his mastery of the correct class codes through his own dress and accent. Allan not only dresses judges; he communicates a repertoire of the law's professional codes and values, and transmits them backstage through the process of dressing, while performing them himself. He underscores the sense that gesture, tone, accent and demeanour are as important as robes and wigs in the production of the face of the law.

Allan's own career path, balanced between studying law and working in retail, also establishes him as an intermediary figure who navigates between the cultures of craft enshrined in the 'downstairs' world of the makers and the cultures of professional knowledge and expertise 'upstairs' in the Bar Room. The spatial organisation of the Ede and Ravenscroft shop marks a hierarchical distinction between the maker of the robes and the wearer of them, and also enacts a spatial distinction between the forms of knowledge and expertise that each form of work entails. Allan's account suggests that the workshop in the basement is governed by the principles of craft, defined by Richard Sennett as 'pride in a job done well for its own sake' (Sennett, 2009, p. 9). Here, specialist expertise takes a different form to that of the law. Allan points out that the robes are made not only with the audience of the legal ceremony or the judiciary in mind. In the workshop, it is the expert eye of other makers that constitutes the most important audience for the robes. Here, the ethos of pride, and the threat of shame, organises the standard and practices of excellence.

This is a trait shared with costume-makers at the theatre, whose concern for historical accuracy or technical perfection will show itself in the perfect linings of costumes never seen by spectators or noticed by actors. The views of the public audience and the actors certainly count, but they are not necessarily what drive the considerations of makers most powerfully - rather it is a shared professional ethos with other makers that is most prominent in how they describe their work (Monks and Maclaurin, 2015, p. 89). Here we see a parallel form of group identity to that of the law. However, rather than this networked identity showing itself in what the makers wear, it emerges in the clothes that they make, established through inherited traditions of craft practices. Alternative forms of expertise and authority to the law emerge through the production of dress. As Sennett argues, within the logic of craft, individual achievement is less important than the expert imitation and repetition of received practices: 'developing one's talents depended on following the rules established by earlier generations' (Sennett, 2009, p. 22). Allan occupies this world of craft, and understands it, while also understanding and transmitting the cultural codes and hierarchies of the world of the wearers - the judges. 
Allan's account of his work as a dresser allows us to peek 'backstage' at a space populated by a variety of audiences (real and imagined) that determine and organise the feelings and meanings produced the act of dressing up. The backstage emerges as a hierarchical place, with the practices of making and dressing in clothes concealed, despite being key to the production of judicial images. Perhaps it is this very act of concealment that maintains the law's 'mysteries'. The division of these 'backstage' worlds from the official accounts of the law may be what helps to manage the law's relationship to its own theatricality - the fact that it requires dressing up, performance and objects to exert its powers. One of the crucial ways in which the mysteries of the law may be maintained is through the careful calibration of its theatricality.

As Julie Stone Peters has suggested, theatricality is a feature of the law that requires careful management. Theatricality is one of the mechanisms by which the law does its work, with its emphasis on habeas corpus, liveness, spectacle and its reliance on the ability of legal performance to produce performative outcomes. At the same time, as Stone Peters argues, 'if law has historically exploited its theatricality ... at the same time it has rebuked or abjured its own theatricality' (Stone Peters, 2008, p. 198). In other words, the law must be theatrical but not too theatrical, lest its performative powers be undermined by the well-established cultural associations of theatricality with falsehood and artifice. ${ }^{10}$ Instead, the law must be just theatrical enough, as she puts it:

'criminal trials must be public but not too public; show trials are bad but secret trials are bad as well; evidence must be relevant, but not so dramatic as to be too relevant (no mutilated bodies on the legal stage); testimony must be live, but not be too lively (witnesses must stay in the box); what witnesses say and show should move juries, but it shouldn't move them too much.' (Stone Peters, 2008, p. 199)

Stone Peters's analysis (which offers an invaluable survey of the various critical approaches taken to the relationship between law and performance) suggests that the law must navigate a balance between theatricality, performance and performativity. In this interview with Christopher Allan, it is clear that the dresser is a figure who also navigates this balance and contributes to its maintenance.

As Barbara Hodgdon notes of the work of the dresser in the theatre: 'Dresser's notes occur infrequently in archival holdings. ... Only rarely does a dresser's name appear in theatrical records' (Hodgdon, 2012, p. 21). Just as with the law, dressers at the theatre tend to be marginalised and relatively invisible in official accounts, despite the instrumental role they play in making the performer's body ready to do its work. This marginality may result from the anxious management of theatricality in both the law and the theatre. In both cases, the 'backstage' work of people like the dresser risks interrupting the power claimed by an apparently 'already-dressed' figure in the production of powerful illusions and real effects in public spaces.

The fantasy of the already-dressed figure of the judge risks disruption by attention to the backstage processes of dressing up and the work of the dresser and maker. Perhaps this disruptive power explains Allan's description of how, inevitably, the newly robed judge is greeted with laughter from friends and family (particularly children) when emerging from their dressing room. Why does this family audience laugh, when laughter of this kind - hilarious and mocking - would invoke such penalties in the courtroom? Perhaps this laughter can tell us something of vulnerabilities of legal dress to the 'charges' of theatricality, once it is extracted from the authorising contexts of ceremony, architecture and language and placed in the 'wrong' setting.

The laughter that greets the judge's first public appearance from family and friends, then, may be a reaction to the uncanny mismatch between the general and the particular that emerges when the judge

\footnotetext{
${ }^{10}$ These associations can be traced back to Plato's Republic and have made a continual reappearance in Western thought ever since, emerging particularly powerfully during the Reformation. Protestant anxieties about iconography also informed the formation of early modern legal practice, as Piyel Halder has argued (see Haldar (1999, p. 117)). One of the best overviews of the seam of anti-theatricality that runs through Western thought can be found in Jonas Barish's The Antitheatrical Prejudice (1981).
} 
appears in the 'wrong' context, backstage. ${ }^{11}$ Schopenhauer explains this form of laughter as emerging from 'the incongruity of sensuous and abstract knowledge. ... All laughter then is occasioned by a paradox' (Schopenhauer, 1989, pp. 51-52). Judicial dress is able to bridge or disavow the tension between the sensuous body-in-the-world of the individual judge and the abstracted concept of the judge in the law, once the dress is worn within the correct frame of the architecture of the court or the RCJ ceremony. However, this paradox risks being exposed by the misalignment between the individual body of the judge and the generic, professional and ritual status of the dress once it is worn out of place.

This tension between the two bodies of the judge - the abstract and ritual one demanded by the dress, the prosaic individual one remembered by the family - produces the laughter that Henri Bergson argues is a risk engendered specifically by clothing. As he suggests, when dress is in fashion ('of its moment), it enables the viewer to maintain the fantasy that it forms a continuity of the wearer's body. As he puts it: 'the idea [does not] occur ... to us to contrast the inert rigidity of the covering with the living suppleness of the object covered' (Bergson, 1911, p. 17). However, anachronistic or ceremonial dress, he argues, reminds the viewer of the material 'stuff of dress, its object-hood and consequently also insists on the object-hood of the body itself. The comic arises he suggests 'when we perceive anything inert or stereotyped, or simply ready-made, on the surface of living society. ... The ceremonial side of social life must, therefore, always include a latent comic element' (Bergson, 1911, p. 20). With the new judge on display to family in advance of the swearing-in ceremony, the distinction of the 'form' of the dress from the ritualised context of the ceremony becomes overwhelmingly comical for its audience. The image of the judiciary, it turns out, is made of 'stuff' and also, as the family discovers, it is the 'stuff that helps to turn people into judges. The judge is both an embodiment of and stand-in for a system that turns out to be astonishingly material.

This materiality turns out to be an important foundation for the performance of the judiciary, and yet its status is repressed by the law's careful management of its own theatricality. The materiality of the law's practices risks exposure (and even laughter) once we pay attention to the figure of the dresser and the makers of the wigs and robes. Working in their backstage spaces, these figures are crucial to the production of judicial images, yet remain in the shadows. The work of makers and dressers remain backstage activities but this interview with Christopher Allan suggests that attending to these forms of work is remarkably enlightening for an understanding of how images of the judiciary begin with the act of dressing up.

\section{References}

Barish J (1981) The Antitheatrical Prejudice. Berkeley: University of California Press.

Bergson H (1911) Laughter: An Essay On The Meaning of the Comic. Gloucester: Dodo Press.

Carlen P (1976) 'The staging of magistrates' justice'. British Journal of Criminology 16, 48-50.

Corfield P (1995) Power And The Professions in Britain 1700-1850. London/New York: Routledge.

Ede and Ravenscroft (2017) 'About us'. Available at https://www.edeandravenscroft.com/about-us/the-company/\#warrants (accessed 17 October 2017).

Haldar P (1999) The function of ornament in Quintilian, Alberti and court architecture. In Douzinas C and Nead L (eds), Law and The Image: The Authority of Art and the Aesthetics of Law. Chicago: University of Chicago Press.

Harwood R (1980) The Dresser. Charlbury: Amber Lane Press.

Hobsbawm E and Ranger T (1983) The Invention of Tradition. Cambridge: Cambridge University Press.

Hodgdon B (2012) Remains at play. Theatre Journal 64, 373-388.

Milner Davies J and Roach Anleu S (eds) (2018) Judges, Judging and Humour. London: Palgrave.

Mitter S (1992) Systems of Rehearsal: Stanislavsky, Brecht, Grotowski and Brook. London: Routledge.

Monks A and Maclaurin A (2015) Readings in Costume. Basingstoke: Palgrave Macmillan.

Moran LJ (2016) Some reflections on the aesthetics of contemporary judicial ceremony. In Virmanipp A (ed.), Political Aesthetics: Culture, Critique and the Everyday. London/New York: Routledge, pp. 159-180.

Moran LJ (2018) What's a box of 'Bakewell Tarts' got to do with it? Performing gender as a judicial virtue in the theatre of justice. In Milner Davies J and Anleu Roach S (eds), Judges Judging and Humour. London: Palgrave Macmillan.

\footnotetext{
${ }^{11}$ See Milner Davies and Roach Anleu (2018) for more on judges and humour.
} 
Mulcahy L (2011) Legal Architecture: Justice, Due Process and the Place of Law. Oxford/New York: Routledge.

Nield S and Leiboff M (eds) (2010) 'Law's theatrical presence'. Special issue of Law Text Culture. Wollongong: University of Wollongong.

Rayner A (2002) Rude mechanicals and the specters of Marx. Theatre Journal 54, 535-554.

Read A (2016) Theatre \& Law. Basingstoke: Palgrave Macmillan.

Roberts H (2012) 'Swearing Mary': the significance of the speeches made at Mary Gaudron's swearing-in as a Justice of the High Court of Australia. Sydney Law Review 34, 493-510.

Roberts H (2014) Telling a history of Australian women judges through courts' ceremonial archives. Australian Feminist Law Journal 40, 147-162.

Schopenhauer A (1989) The world as will and idea. In Morreal J (ed.), The Philosophy of Laughter and Humour. Albany: State University of New York Press, pp. 51-64.

Sennett R (2009) The Craftsman. London: Penguin.

Silverstone C (2005) Shakespeare live: reproducing Shakespeare at the 'new' Globe Theatre. Textual Practice 19, 31-50.

Stanislavski K (2008) An Actor's Work, trans. by Jean Benedetti. Abingdon: Routledge.

Stone Peters J (2008) Legal performance good and bad. Law, Culture and The Humanities 4, 179-200.

Turner V (1974) Liminal to Limonoid in Play, Flow and Ritual: An Essay in Comparative Symbology. Houston: Rice Institute Pamphlet.

Watt G (2013) Dress, Law and Naked Truth. A Cultural Study of Fashion and Form. London: Bloomsbury.

Woodcock T (2014) Legal Habits: A Brief Sartorial History of Wig, Robe and Gown. London: Ede and Ravenscroft/Good Books.

Yablon CM (1995) Judicial drag: an essay on wigs, robes and legal change. Wisconsin Law Review 1995, 1129-1154.

Cite this article: Monks A (2018). Dressing the law. International Journal of Law in Context 14, 479-492. https://doi.org/ $10.1017 /$ S1744552318000198 